\title{
Verdensdagen for selvmordsforebygging
}

LEVE - Landsforeningen for etterlatte ved selvmord - er nasjonal koordinator av Verdensdagen for selvmordsforebygging 10. september. Dagen markeres over hele verden og i Norge i regi av LEVEs fylkeslag og fagmiljøene innenfor selvmordsforebygging. I år er mottoet for Verdensdagen "Selvmordsforebygging i et flerkulturelt samfunn". Vi oppfordrer alle til å støtte opp om årets markeringer, og du finner mer informasjon om markeringene i ditt fylke ved å gå inn på www.leve.no og nettsiden til fylkeslaget ditt.

\section{Litteratur og selvmord - nasjonal markering 2. og 3. september}

Den nasjonale markeringen av Verdensdagen er i år et todagers seminar på Litteraturhuset i Oslo 2. og 3. september under overskriften "Litteratur og selvmord”. På seminaret $\phi$ nsker vi å unders $\phi$ ke forholdet mellom forfatterrollen, biografi, filosofi og selvmordet som litterært tema, og vi vil presentere et utsnitt av samtidslitteraturens fremstillinger av selvmordsproblematikken.

Programmet er som følger:

Fredag 2. september

18:00 “Sorgen var strengen med mest lyd i”. Forfatterintervju med Guro Hoftun Gjestad. Intervjuer: Kari Wille Rekdal

19:00 “Meningen med selvmord”. Filosofisk debatt: Arne Johan Vetlesen og Lars Fredrik Svendsen. Intervjuer: Henning Herrestad

\section{Lørdag 3. september}

13:00 "Å skrive om selvmord”.

Forfattersymposium med Beate Grimsrud, Mona Høvring og Merete Morken Andersen. Intervjuer: Kari Wille Rekdal

15:00 “Jeg vil ikke d $\phi$, jeg vil bare ikke leve".

Monolog fra boken v/ skuespiller Kristin Grue og dramaturg Line Rosvoll. Forfatterintervju med Ann Heberlein (SWE).

Intervjuer: Henning Herrestad.

20:00 "Legender om et selvmord". Forfatterintervju med David Vann (USA). Intervjuer: Hilde Stubhaug

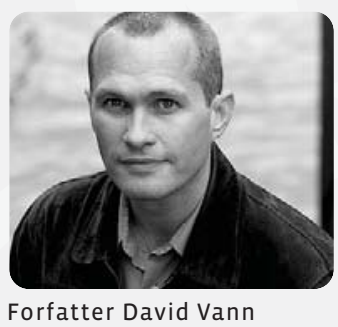

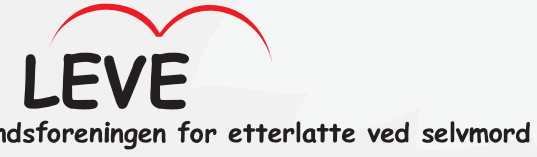

Billetter vil bli solgt ved døra og koster 100,- for fredag og lørdag formiddag. Intervjuet med David Vann på lørdag koster kr. 50,I tillegg vil det bli salg av boken om Minneteppet til Eline Medbøe. Minneteppet vil også bli stilt ut på Litteraturhuset.

\section{$I \mathcal{A} S \mathcal{P}$ \\ Verdensdagen for selvmordsforebygging}

